\title{
Anakayaların toprak özellikleri ve toprak erodibilitesi üzerine etkileri: Çemrengeç deresi yağış havzası örneği
}

\author{
Mahmut Reis,", (iD, Seda Tat ${ }^{\mathrm{a}}$ (iD, Bülent Abız ${ }^{\mathrm{a}}$ (i)
}

\begin{abstract}
Özet: Erodibilite, toprakların tamamen kendi bünyelerindeki çeşitli özelliklerinden kaynaklanan ve eroziv etmenlere karşı direncini veya erozyona uğrama eğilimini gösteren bir niteliktir. Toprak erodibilitesini etkileyen toprak özellikleri büyük ölçüde anakayadan kaynaklanmaktadır. Bu nedenle farklı anakayalar, farklı erodibilite özelliklerine sahip topraklar oluşturmaktadır. Yapılan bu araştırmayla bazı anakayaların toprak erodibilitesi ve toprak erodibilitesini etkileyen toprak özellikleri üzerindeki etkileri incelenmiştir. Araştırma Türkiye'de Kahramanmaraş ili sınırları içerisindeki Çemrengeç yağış havzasında gerçekleştirilmiştir. Havzada yer alan Kireçtaşı, Kumtaşı, Kuvarsit ve Mikaşist anakayaları üzerinde gelişen topraklardan örnekler alınarak, toprakların tekstür, organik madde, strüktür yapısı, nem ekivalanı, permeabilite gibi toprak özellikleri ile toprak erodibilite indeksleri belirlenmiştir. Toprak erodibilite indeks değerlerinden dispersiyon oranı, erozyon oranı, kolloid/nem ekivalanı oranı, kil oranı ve toprak erodibilite faktörü değerleri tespit edilmiştir. Böylece toprakların erodibilite değerleri 5 farklı erodibilite indeksine göre incelenerek, farklılıkların aynı yönde olup olmadığı araştırılmıştır. Toprak erodibilite indeks değeri üzerinde etkili olan toprak özellikleri varyans analizi ve korelasyon testleriyle istatistiksel olarak karşılaştırılmıştır. Elde edilen sonuçlara göre genel olarak toprak erodibilite değerleri anakayalara göre Kumtaşı $>$ Kuvarsit $>$ Mikaşist $>$ Kireçtaşı şeklinde olduğu tespit edilmiștir. Toprak özelliklerinden ise kil yüzdesinin toprak erodibilitesini etkileyen en önemli toprak özelliği olduğu sonucu ortaya çımıştır. Anahtar kelimeler: Anakaya materyali, Dispersiyon oranı, K faktörü, Toprak erodibilitesi, Toprak tekstürü
\end{abstract}

\section{Effects of parent material on soil properties and soil erodibility: The case study of Cemrengec watershed}

\begin{abstract}
Erodibility is a property that results from the various properties of soils in their own structure and shows their resistance to erosive factors or their tendency to erosion. Soil properties affecting soil erodibility are significantly originated parent material. Thus, different parent materials form soils having different erodibility properties. In this study, the effects of some parent material on soil erodibility and soil properties influencing soil erodibility was investigated. The study was carried out Cemrengec Watershed within city of Kahramanmaras in Turkey. Soil characteristics such as texture, organic matter, structure, moisture equivalent and permeability, and soil erodibility indices was determined by taking samples from soils developed from limestone, sandstone, quartzite and mica schist in the watershed. Soil erodibility indices values, dispersion ratio, erosion ratio, colloidal moisture equivalent ratio, clay ratio and soil erodibility factor were calculated. So, erodibility values of soil were examined by taking 5 different erodibility indices into account. And then, whether or not there were differences among soil erodibility values was investigated. Soil properties having influence on soil erodibility indices were statistically compared by variance analysis and correlation test. According to results, soil erodibility values of parent materials ranged as sandstone>quartzite >mica schist>limestone. Besides, clay percentage was the most important soil property affecting soil erodibility taking soil properties into account.
\end{abstract}

Keywords: Parent material, Dispersion ratio, K factor, Soil erodibility, Soil texture

\section{Giriş}

Erozyon, doğal dengenin en önemli unsuru olan toprağ yerinde tutan ve koruyan bitki örtüsünün insanoğlu tarafından değişikliğe uğratılması sonucunda büyük ölçüde hız kazanmış toprak aşınması ve taşınması olayıdır (Balcı, 1996; Babalık, 1999). Erodibilite, toprakların tamamen kendi bünyelerindeki çeşitli özelliklerinden kaynaklanan ve eroziv etmenlere karşı direncini veya erozyona uğrama eğilimini gösteren bir niteliktir. $\mathrm{Bu}$ nedenle erodibilite, erozyondan farklı olarak bir eğilimi veya potansiyeli ifade eden bir kavramdır. Nitekim sık ve koruyucu bir bitki örtüsü, örneğin sık bir orman altında bulunan bir toprakta hiç bir etkin erozyon görülmediği halde, bu toprağın bazı yapısal özelliklerinden kaynaklanan erodibilitesi yüksek olabilir. Böyle toprakların koruyucu örtüsünün kaldırılması, topoğrafik ve yağış koşullarının elverişli olması halinde büyük bir erozyon olayını kaçınılmaz kılabilir (Balc1, 1996).

Toprakların erozyona karşı duyarlılıkları sahip oldukları erozyonu etkileyen özelliklerin farklılığından ileri gelmektedir. Erozyonu etkileyen en önemli toprak özellikleri; tekstür, strüktür, hidrolik geçirgenlik, organik madde kapsamı olarak söylenebilir. Toprak tekstürü, toprakların erozyona uğramasında en önemli faktörlerden birisidir. a Kahramanmaraş Sütçü İmam Üniversitesi, Orman Fakültesi, Orman Mühendisliği Bölümü, Kahramanmaraş

@ * Corresponding author (İletişim yazarı): mreis@ksu.edu.tr

$\checkmark \quad$ Received (Geliş tarihi): 11.08.2021, Accepted (Kabul tarihi): 03.11.2021
Citation (Atıf): Reis, M., Tat, S., Abız, B., 2021. Anakayaların toprak özellikleri ve toprak erodibilitesi üzerine etkileri: Çemrengeç deresi yağış havzası örneği. Turkish Journal of Forestry, 22(4): $353-361$ DOI: $10.18182 /$ tjf. 981638 
Monopartiküler (teksel) bir yapı gösteren kumlu topraklar büyük bir dağılma özelliğine sahiptirler. Oysa geçirgenlikleri çok fazladır. Killi topraklar ise yağmur damlalarının çarpma ve dağıtma etkilerine karşı büyük bir dayanıklılık gösterirler. Ancak bu dayanıklılığında kritik bir noktası vardır. Bu nokta aşıldığı anda killi topraklar kumlu topraklardan daha kolay bir şekilde dağılır ve taşınırlar (Doğan vd., 2000).

Erozyon oluşumunda suyun en önemli etkisi toprağ dispersleştirme ve taşıma etkisidir. Topraklar sahip oldukları fiziksel, kimyasal özellikleri ve organik maddeler yardımıyla suyun aşındırma ve taşıma etkisine değişik oranlarda karşı koymaktadırlar. Diğer bir deyimle aynı dış erosiv etkenler altında farklı topraklar, farklı şekilde erozyona uğramaktadır. $\mathrm{Bu}$ farklılık toprak özelliklerinin yanında erodibilite karakteristiklerinin farklı olmasından kaynaklanmaktadır. Toprakların erodibilite karakteristikleri ile birçok özellikleri arasında yakın ilişkiler bulunmuştur. Bu ilişkiler yardımıyla erodibilite indeksleri geliştirilmistir (Yüksek, 2001). Erozyon durumu; toprağın aşınabilirliğine, arazinin özelliklerine ve arazi kullanım durumuna bağlı olarak değiştiği gibi yağışın erozivitesine göre de değişebilir (Lal, 1988; Okatan vd., 2000).

Bir havzada yüzeysel akışın meydana gelmesini etkileyen öğeler aynı zamanda o havzada oluşacak sel ve erozyonun boyutlarını da etkilemektedir. Bu öğeler; havzanın iklimi, topografik yapısı, toprağı ve ana materyali, doğal bitki örtüsü ve insan unsurudur. Toprak oluşumunun temel maddesi olan anakaya en önemli toprak yapan faktördür. Ancak anakayanın toprağın gelişimindeki etkinliği bölgesel olarak değişir. Özellikle serin ve nemli iklimin etkisi altındaki bölgelerde toprağın gelişiminde anakaya iklimden daha az etkilidir. Buna karşılık Türkiye'nin de yer aldığı 1lıman kuşaktaki toprak gelişimi olaylarında anakaya özelliklerinin iklim özellikleri kadar etkili olduğu anlaşılmıştır (Kantarcı, 1987).

Toprakların oluşturduğu anamateryaller fiziksel, kimyasal ve minerolojik yapı ve bileşimleri bakımından farklılıklar gösterirler. Bu nedenle de ayrışma süreçleri de birbirinden farklıdır. Nitekim püskürük, tortul ve metamorfik (başkalaşım) kayalar, değişik özellikler ve ayrışma süreçlerine sahiptir. Toprak profilinin gelişmesinde en belirgin etmenlerden birisi olan anamateryalin nitelikleri ve oluşum orijinlerinin bilinmesi önem taşır (Balcı, 1996).

$\mathrm{Bu}$ araştırmada, Türkiye'nin Doğu Akdeniz bölgesinde yer alan Kahramanmaraş Çemrengeç Deresi Yağış Havzası'nda farklı anakayalar üzerinde gelișen toprakların erozyon eğilim değerleri belirlenmiş ve bu değerler arasındaki farklılıkların istatistiki olarak önemli olup olmadığı ortaya konulmuştur.

\section{Materyal ve yöntem}

\subsection{Materyal}

Araştırma alanı Türkiye'nin Doğu Akdeniz Bölgesinin Kahramanmaraş ili sınırları içerisinde yer almaktadır. Araştırma alanının Kahramanmaraş Merkeze olan uzaklığ ortalama $53 \mathrm{~km}$ olup, Suçatı yöresinin orman, tarım, mera alanları ile kaplı Çemrengeç Deresi Yağış Havzasında

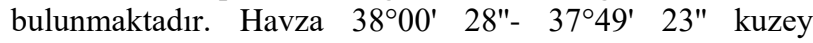
enlemleri ile $36^{\circ} 39^{\prime} 29^{\prime \prime}-36^{\circ} 47^{\prime} 33^{\prime \prime}$ doğu boylamları arasında yer almaktadır (Şekil 1).

Araştırma alanı Karasal iklim ile Akdeniz iklimi arasında bir geçiş iklimi özelliğine sahiptir. Genellikle yazlar sıcak ve kurak, kışlar soğuk ve karlıdır. Yııllık yağı̧̧ miktarı 700 mm'nin üzerindedir. Yağışlar genellikle kış ve ilkbahar aylarında görülmektedir. Araştırma alanının yıllık ortalama sıcaklığ $16.7{ }^{\circ} \mathrm{C}$, maksimum sicaklığ $45.2{ }^{\circ} \mathrm{C}$ (Temmuz), minimum sıcaklığ 1 ise $-9.6{ }^{\circ} \mathrm{C}$ (Şubat)'dır. Araştırma alanı vejetasyon periyodu dikkate alındığında kurak iklim özellikleri gösteren bir alandır. Araştırma alanı Türkiye'nin 3 büyük flora bölgesinden biri olan Akdeniz element kesiminde yer almaktadır (Anşin, 1983). Araştırma alanında, Juniperus sp., Pinus nigra, Cedrus libani ve Pinus brutia odunsu bitki türleri bulunmaktadır. Galium verum subsp. verum, Hypericum scabrum, Allium trachycoleum, Ranunculus repens, Sedum hispanicum var. semiglabrum, Fumaria asepala gibi otsu bitki türleri bulunmaktadır.

\subsection{Yöntem}

Yapılan bu araştırmayla farklı anakayalar (kireçtaşı, kuvarsit, kumtaşı, mikaşist) üzerinde gelişen toprakların erodibilite değerleri (dispersiyon oranı, erozyon oranı, kil oran1, kolloid/nem ekivalanı oran1 ve $K$ faktörü) belirlenmiştir. Araştırma alanında yer alan üst toprakların (0$20 \mathrm{~cm}$ ) çevre koşullarından fazlaca etkilenmesi nedeniyle anakayalardan oluşan toprağın özelliklerini daha iyi yansitabilmek amaciyla alt toprak olarak ifade edilen 20-50 $\mathrm{cm}$ ve $>50 \mathrm{~cm}$ toprak kademelerinin özellikleri araştırmaya konu olmuştur.
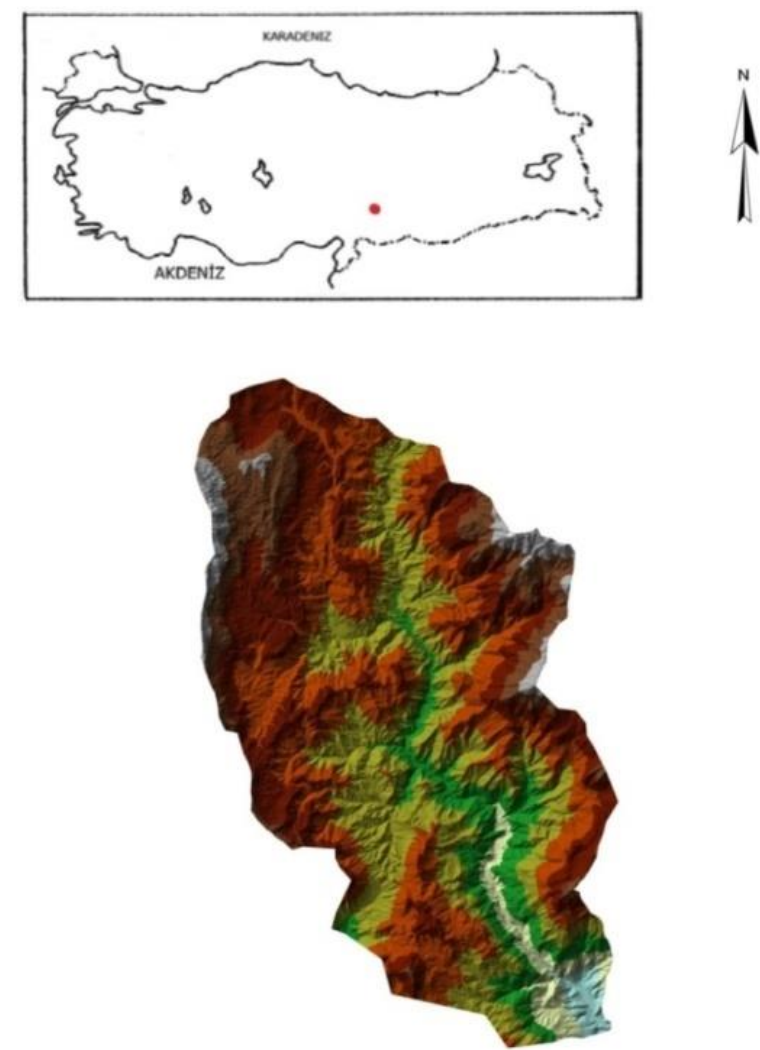

Şekil 1. Araştırma alanının sayısal arazi modeli ve Türkiye haritasındaki konumu 
Araştırmada 4 farklı anakaya grubuna göre; faktöriyel deneme deseni esasları gözönünde bulundurularak kumtaşı anakayasından 14, kireçtaşı anakayasından 15, kuvarsit anakayasından 14, mikaşist anakayasından 13 adet olmak üzere toplam 56 adet toprak profili alınmıştır. İki derinlik kademesinden toplam 112 adet strüktürü bozulmuş toprak örneği ile aynı sayıda strüktürü bozulmamış hacım ağırlığı silindir örneği alınmıştır. Araştırmada anakayanın hemen üzerinde yer alan alt toprak kademesinin özelliklerini ortaya koymak amaciyla $20-50 \mathrm{~cm}$ ve $>50 \mathrm{~cm}$ derinlik kademelerinden alınan toprak örneklerinden elde edilen verilerin ortalaması alınarak değerlendirme yapılmıştır.

Yapılan bu araştırmayla farklı anakayalar üzerinde gelişen toprakların tekstür yapısı, organik madde (SOM), permeabilite $(\mathrm{P})$, nem ekivalanı (ME), dispersiyon oranı (DR), erozyon oranı (ER), kolloid-nem ekivalanı (C-MER), kil oranı (CR) ve toprak erodibilite faktörü $(\mathrm{K})$ belirlenmiştir. Toprakların tekstür tayini Bouyoucos'un hidrometre yöntemine göre (Bouyoucos, 1935), nem ekivalanı "Soil Moisture Pressure Plate" kullanılarak seramik levhalı alçak basınç aletinde 1/3 atmosfer basınç altında (Gülçur, 1974), permeabilite Darcy kanununa göre belirlenmiştir. Middleton'un dispersiyon oranı, 2 mm'lik elekten geçirilmiş toprağın hiçbir mekanik ve kimyasal dispersleşmeye tabi tutulmadan saf suda çalkalanması ile elde edilen toprak solüsyonunda mekanik analizle tayin edilen toz+kil miktarının, topraktaki mevcut gerçek toz+kil miktarına bölünmesi ile elde edilmiştir (Lutz ve Chandler, 1947).

$\mathrm{Bu}$ indekse göre toprakların erozyona dayanıklılık sınırı $\% 15$ olarak kabul edilmiş olup, \% 15'ten büyük dispersiyon oranına sahip topraklar erozyona duyarlı olarak değerlendirilmektedir. Kolloid/Nem Ekivalanı oranı, toprağın suyu geçirgenliğini, yani permeabilitesini gösteren bir indeks olarak kabul edilir (Öztan, 1980). Kolloid/Nem Ekivalanı oranının yüksek olmasının, toprağın tarla kapasitesinin düşük olmasını, dolayısıyla da infiltrasyonun yükselmesi ve yüzeysel akışın azalması sonucunu doğurduğu saptanmıştır. Kolloid-Nem Ekivalanı oranı 1.5 'den büyük olan topraklar erozyona dayanıklı, 1.5'den küçük olanlar ise erozyona dayanıksı olarak kabul edilmektedir. Erozyon oranı, dispersiyon oranının aynı toprağın kolloid/nem ekivalanı oranına bölünmesiyle bulunmuştur (Özyuvacı, 1975; Öztan, 1980). Erozyon oranı 10'dan büyük olan topraklar erozyona dayanıksız, 10'dan küçük olanlar ise erozyona dayanıklı olarak kabul edilmektedir. Bouyoucos (1935) tarafindan önerilen "kil oranı" topraktaki \%kum+\%toz değerinin \%kil değerine bölünmesi ile elde olunur. $\mathrm{Bu}$ oranın büyümesi ile toprakların erodibilitesi yükselmektedir. Diğer bir deyimle topraktaki kum ve toz fraksiyonlarının yüksek olması veya kil fraksiyonunun düşük olması, topraklarda erozyon eğilimini arttırmaktadır. Wishmeier ve Smith tarafından 1978 yılında geliştirilen Üniversal Toprak Kayıpları Tahmin Modeli (USLE) denkleminde yer alan faktörlerden biri olan toprak erodibilite faktörü, toprakların organik madde içeriği, tekstür, strüktür ve su geçirgenliği değerine bağlı olup aşınmaya karşı direnci göstermektedir (Sönmez, 1994). Bu değer küçüldükçe aşınmaya karşı direnç artmaktadır. Bazı topraklar aynı eroziv kuvvetler karşısında oldukça dirençli oldukları halde, bazı topraklar ise aynı kuvvetler altında kolayca çözünür ve dağılarak erozyona uğrarlar. Bu hususlar dikkate alınarak toprakların kendi iç bünyelerine bağlı aşağıdaki özellikleri dikkate alınmak suretiyle, toprak erodibilite faktörünü veren bir nomograf geliştirilmiştir. Nomografta kullanılan faktörler
(1) toz+çok ince kum (\%), (2) kum miktarı (\%), (3) organik madde miktarı (\%), (4) toprak strüktürü ve (5) permeabilitedir. Burada söz konusu olan "toz+çok ince kum" çapları $0.002 \mathrm{~mm}$ ile $0.10 \mathrm{~mm}$ arasındaki taneciklerden oluşan fraksiyondur. Kum ise $0.10 \mathrm{~mm}$ ile $2.0 \mathrm{~mm}$ çap dağılımındaki taneciklerdir (Balcı, 1996). K faktörüne göre toprakların erodibilite dereceleri Çizelge 1'de gösterilmiş̧ir.

Arazi ve laboratuvarda yapılan çalışmaların sonucunda elde edilen veriler bilgisayarda istatistik yöntemlerle değerlendirilmiştir. Toprakların erozyon eğilimi ile bazı fiziksel özelliklerinin 4 farklı anakaya grubuna göre farklılık gösterip göstermediği varyans analizi uygulanarak karar verilmiştir. Bunun sonucunda elde edilen ortalamaların karşılaştırılması ise Duncan Testi ile yapılmıştır. Çeşitli toprak özellikleri ile erodibilite özellikleri arasındaki ilişkiler korelasyon testi ile araştırılmıştır. İstatistik işlemler SPSS paket programı (Versiyon 20) programı kullanılarak yapılmıştır.

\section{Bulgular ve tartışma}

Araştırmanın gerçekleştiği alanda olduğu gibi kurak ve yarı kurak alanlarda anakayalardan ayrışan toprakların özellikleri tam olarak anakayaların özelliklerini gösteremeyebilmektedir. Toprak oluşumunda anamateryalin etkisinin egemen olabilmesi için iklim koşullarının ayrışma için elverişsiz olması gerekir. Sıcaklık ve nemin optimumda olduğu bölgelerde, kısa bir zamanda ve hızlı bir şekilde gerçekleşen fiziksel ve kimyasal ayrışma sonunda anakayanın etkisi oldukça azalır. Tropik bölgeler bunun tipik örneklerini oluşturur. Fakat ayrışma için elverişsiz kurak ve soğuk, hatta soğuk-1lıman bölgelerde ayrışma çok yavaş olmakta, bunun sonucunda da toprak özellikleri çoğunlukla anakayanın damgasını taşımaktadır (Çepel, 1988). Kantarcı (1980 ve 2000)'da benzer ya da farklı ana materyallerden oluşan toprakların, farklı tiplerde topraklar olduğunu belirtmektedir.

Yapılan araştırma sonucunda tüm çevresel ve iklimsel kısıtlara rağmen anakayaların üzerinde oluşan toprakların genel olarak anakayaların özelliklerini yansıttığ toprak kademelerinin araştırmaya konu olmasının etkili olduğu söylenebilir.

Farklı erodibilite indekslerinin farklı toprak verilerinden yararlanarak belirlenmesi nedeniyle 5 farkl 1 erodibilite indeksine göre toprakların aynı erozyon eğilimi gösterip göstermediği araştırılmıştır. Araştırma alanı topraklarının yapılan analizleri sonucu bütün anakaya gruplarında ve bütün erodibilite indeksleri için toprakların genel olarak erozyona duyarlı olduğu tespit edilmiştir. Ancak yapılan istatistiksel analizlere göre tüm toprakların erozyona duyarlı olmasına rağmen erozyona hassasiyet derecelerinin farklı olduğu görülmüştür.

Çizelge 1. Toprakların erodibilite dereceleri (K) ve anlamları (Doğan ve Güçer, 1976)

\begin{tabular}{cl}
\hline Erodibilite faktörü $(\mathrm{K})$ & Erodibilite derecesi \\
\hline $0.00-0.05$ & Çok az aşınabilir toprak \\
$0.05-0.10$ & Az aşınabilir toprak \\
$0.10-0.20$ & Orta derecede aşınabilir toprak \\
$0.20-0.40$ & Kolaylıkla aşınabilir toprak \\
$0.40-0.60$ & Çok kolaylıla aşınabilir toprak \\
$>0.60$ & Aşırı derecede kolay aşınabilir toprak \\
\hline
\end{tabular}


Araştırma alanı topraklarının ortalama kum değerleri, Kumtaşı anakayası üzerinde bulunan topraklarda \%67.4, Kireçtaşı anakayası üzerinde bulunan topraklarda \%43.47, Kuvarsit anakayası üzerinde bulunan topraklarda \%84.6, Mikaşist anakayası üzerinde bulunan topraklarda $\% 59.56$ olarak belirlenmiştir. Ortalama kil değerleri, Kumtaşı anakayası üzerinde bulunan topraklarda \%14.16, Kireçtaşı anakayası üzerinde bulunan topraklarda \%35.24, Kuvarsit anakayası üzerinde bulunan topraklarda \%6.21, Mikaşist anakayası üzerinde bulunan topraklarda \%19.63 olarak belirlenmiştir. Ortalama toz değerleri, Kumtaşı anakayası üzerinde bulunan topraklarda \%18.44, Kireçtaşı anakayası üzerinde bulunan topraklarda \% 21.29, Kuvarsit anakayası üzerinde bulunan topraklarda \%9.18, Mikaşist anakayası üzerinde bulunan topraklarda \%20.82 olarak belirlenmiştir (Şekil 2). Anakayalar ve Toprakların Karakteristik Özellikleri ve Pratik Teşhis Anahtarları adlı eserde Kireçtaşı anakayasından oluşan toprakların ağır tekstürlü, Mikaşist anakayasından oluşan toprakların orta tekstürlü, kuvarsit anakayasından oluşan toprakların hafif tekstürlü (kaba taneli) ve kumtaşı anakayasından oluşan toprakların hafif tekstürlü oldukları ifade edilmektedir.

Ortalama organik madde değerleri, Kumtaşı anakayası üzerinde bulunan topraklarda \%3.11, Kireçtaşı anakayası üzerinde bulunan topraklarda \%3.94, Kuvarsit anakayası üzerinde bulunan topraklarda \%2.62, Mikaşist anakayası üzerinde bulunan topraklarda \%3.14 olarak belirlenmiştir (Şekil 3). Elde edilen organik madde değerlerinin genel olarak tüm anakaya gruplarında düşük değerler verdiği belirlenmiş olup, bu durum; toprakların alt toprağı temsil ettiğinden dolayı organik maddenin bu katmanda zaten düşük olması ile ifade edilebilir. Bunun yanında, araştırma alanının yarı kurak özellikler göstermesi ve ortalama sıcaklıkların fazla olması nedeniyle organik materyallerin hızlı bir şekilde ayrıştı̆ğ bilinen bir gerçektir. Hızlı bir şekilde ayrışan organik materyallerin araştırma alanını da içerisine alan yörede bitki örtüsünün zayıflı̆̆ 1 nedeniyle üst toprak tabakasından yağış ve rüzgârlarla gerçekleşen erozyon sonucu alandan uzaklaştığı ve alt toprak kısmına çoğunlukla inemediği ile açıklanabilir. Günay (2008), özellikle kurak ve yarı kurak bölgelerde toprağı koruyan bitki örtüsünün kaldırılması durumunda hafif bünyeli uçucu özelliğe sahip topraklarda rüzgâr erozyonunun büyük sorunlar yaratabildiğini belirtmektedir. Genel olarak toprakların alt toprak kademelerinin organik maddece zayıf olduğu çeşitli araştırmalarla ortaya konulmuştur (Reis, 1997; Okatan, 1986; Aydın, 2000; Yazıcı ve Turan, 2016). Toprak organik maddesi mineral tanecikleri birleştirerek toprak strüktürünün gelişmesine etki etmektedirler. Ayrıca ayrışmamış organik artıklar toprağı yağmur taneciklerinin aşındırıcı etkisine karşı korumaktadırlar. Yüksek oranda ayrışmış organik maddelere humus adı verilir ve humus toprak taneciklerini birbirine yapıştırarak erozyona daha dirençli hale getirmektedir (O’Geen vd., 2006).

Ortalama permeabilite değerleri, Kumtaşı anakayası üzerinde bulunan topraklarda $102.91 \mathrm{~cm} /$ saat, Kireçtaş1 anakayası üzerinde bulunan topraklarda $43.57 \mathrm{~cm} / \mathrm{saat}$, Kuvarsit anakayası üzerinde bulunan topraklarda 101.6 $\mathrm{cm} /$ saat, Mikaşist anakayası üzerinde bulunan topraklarda $116.2 \mathrm{~cm} /$ saat olarak belirlenmiştir (Şekil 4). Toprakların permeabilite değerleri genel olarak toprak tekstürü ile yakından ilgilidir. Kireçtaşı anakayası üzerinde gelişen toprakların diğer anakayalar üzerinde gelişen topraklara göre daha düşük permeabilite değerine sahip olmasının temel nedeni ortalama kil değerinin (\%35.24) diğer anakaya gruplarına göre çok yüksek olmasından kaynaklanmaktadır. Toprakların kil taneciklerinin suyu bünyesine aldıktan sonra şişmesi nedeniyle mikro boşluklarının tıkanması, toprakların su geçirgenliğinin azalmasına neden olmaktadır (Özhan, 2004). Permeabilite toprakların tekstürü, strüktürü ve hacim ağırlığının bir fonksiyonu olarak toprak içerisine giren suyun oranı olarak kabul edilir. Yüksek permeabiliteye sahip olan topraklarda suyun toprağa girişi hızlı olduğundan yüzeysel akış ve buna bağlı olarak toprak erozyonu azalmaktadır (O’Geen vd., 2006).

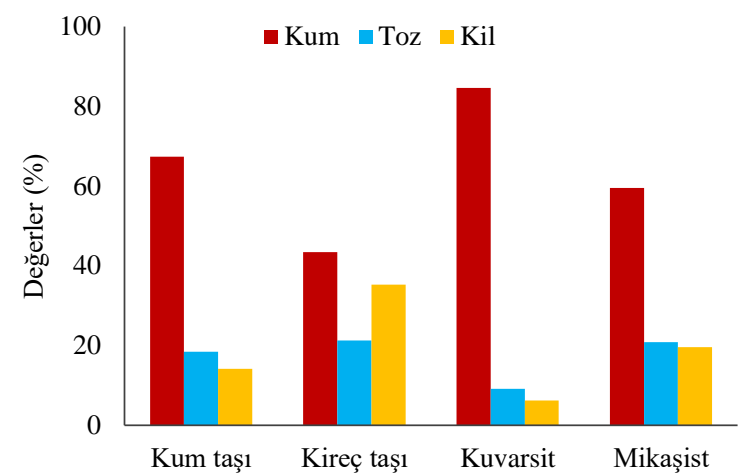

Şekil 2. Farklı anakaya gruplarına göre ortalama kum, toz ve kil değerlerinin değişimi

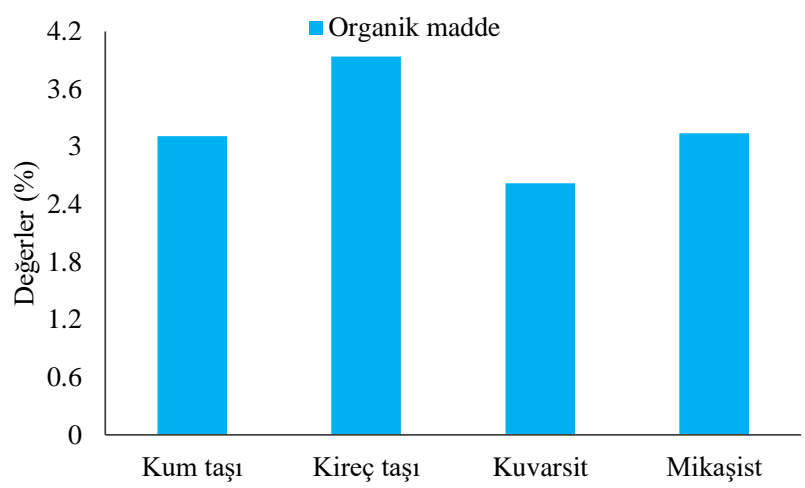

Şekil 3. Farklı anakaya gruplarına göre ortalama organik madde değerlerinin değişimi

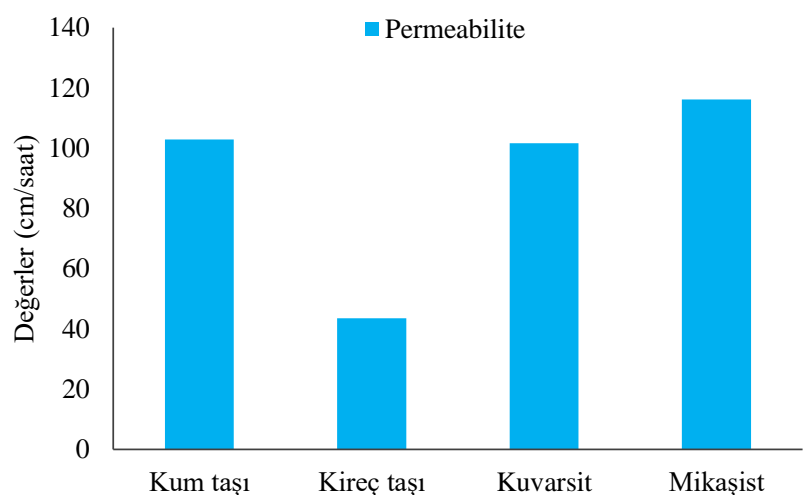

Şekil 4. Farklı anakaya gruplarına göre ortalama permeabilite değerlerinin değişimi 
Ortalama dispersiyon oranı değerleri, Kumtaşı anakayası üzerinde bulunan topraklarda \%93.69, Kireçtaşı anakayası üzerinde bulunan topraklarda \%68.48, Kuvarsit anakayası üzerinde bulunan topraklarda \%118.49, Mikaşist anakayası üzerinde bulunan topraklarda 81.36 olarak belirlenmiştir (Şekil 5). Yılmaz ve Alagöz (2008), dispersiyon oranı, erozyon oranı ve kolloid nem ekivalanı oranları bakımından kiltaşı ve kireçtaşı anakayalarından oluşan toprakları erozyona karşı dayanıksız olduğunu belirlemiştir. Kireçtaşı anakayasının diğer anakayalara göre dispersiyon oranının daha düşük olmasının nedeni yüksek kil ve toz içeriğidir (\%56.53). Varyans analizi ve Duncan testine göre dispersiyon oranları bakımından; kuvarsit anakayası üzerinde gelișen toprakların, diğer anakayalar üzerinde gelișen topraklara göre \% 5 yanılma olasılığı ile farklı olduğu belirlenmiştir (Çizelge 2). Korelasyon analizi sonuçlarına göre ise dispersiyon oranının; kum miktarı ve permeabilite ile pozitif yönde, kil ve toz miktarı, organik madde ile negatif yönde anlamlı (\%1 yanılma olasılığı ile) ilişki gösterdiği tespit edilmiştir (Çizelge 3). Kil ve toz içeriği fazla olan toprakların suda çözünmesi daha zordur bu nedenle erozyona karşı daha dayanıklıdır (Özhan, 2004). Kuvarsit anakayasının yüksek dispersiyon oranı vermesinin temel nedeni ise düşük kil yüzdesine sahip olmasıdır (\%6.21). Evans (1980), benzer şekilde kil içeriği \% 9-30 arasındaki topraklarda erozyona hassasiyetin yüksek olduğunu belirlemiştir. Aynı şekilde Karagül (1999), kil fraksiyonlarının artışının dispersiyon oranı değerlerini azalttığını belirlemiştir. Farmer (1973), laboratuvar şartlarında toprak partiküllerinin nispi çözünebilirliğini araştırdığı çalışmasında; orta ve kaba partiküllerin toprak kütlesinden daha kolay ayrıldığını, kil partikülllerinin ise çözünmeye karşı daha dirençli olduğunu belirlemiştir. Ngatunga vd. (1984) ile Lal (1988), dispersiyon oranı değeri yağışın etkisi ile toprak strüktüründe meydana gelen değişimin değerlendirilmesinde kullanılan bir parametre olduğunu ve oran değeri $\% 15^{\prime}$ den küçük olan toprakların erozyona karşı dayanıklı olduğunu belirtmiştir. Erol vd. (2009) yaptıkları çalışmada; tüm arazi kullanımlarında (tarım, mera, orman) dispersiyon oranının $\% 15$ 'den fazla olduğunu hesaplamışlar ve toprakların erozyona dayanıksız olduğunu vurgulamışlardır.

Ortalama kolloid/nem ekivalanı oranı değerleri, Kumtaşı anakayası üzerinde bulunan topraklarda 0.49 , Kireçtaşı anakayası üzerinde bulunan topraklarda 1.03, Kuvarsit anakayası üzerinde bulunan topraklarda 0.28, Mikaşist anakayası üzerinde bulunan topraklarda 0.60 olarak belirlenmiştir (Şekil 6). Varyans analizi ve Duncan testi sonuçlarına göre kolloid/nem ekivalanı oranı bakımından; kuvarsit, kumtaşı ve mikaşist anakayaları ile kireçtaşı anakayası arasında (0.05 yanılma olasılığı ile) önemli farklılıklar tespit edilmiştir (Çizelge 2). Elde edilen Korelasyon analizi sonuçlarına göre ise kolloid/nem ekivalanı oranının; kil ve toz miktarı, organik madde ile pozitif yönde, kum miktarı, permeabilite, ile negatif yönde anlamlı (\%1 yanılma olasılığı ile) ilişki gösterdiği tespit edilmiştir (Çizelge 3). Kolloid/nem ekivalanı oranına göre tüm topraklar erozyona dayanıksız olmasına rağmen, diğer anakayalara göre kıyaslandığında kireçtaşı anakayası üzerinde gelişen toprakların yüksek kil değeri nedeniyle nispeten erozyona daha dayanıklı olduğu söylenebilir. Benzer şekilde Yamanlar (1962), kolloid/nem ekivalanı oranının toprağın kil fraksiyonlarına bağlı olarak arttığını tespit etmiştir. Toprak bünyesinin tayin eden fraksiyonlardan kum ve toz gibi kaba tanecikler taşınmaya karşı daha dirençlidirler. Buna karşıllk kil gibi ince kolloidal fraksiyonlar taşınmaya karşı dirençsiz fakat çözülmeye karşı dirençlidirler. Nitekim Richter ve Negendank (1977), toz içeriği \%40-60 ve daha fazla olan topraklarda erozyona duyarlılığın en yüksek olduğunu bildirmiştir. Morgan (1985), kil tanecikleri organik madde ile birlikte dayanıklı toprak agregatları oluşturdukları için böyle topraklar erozyona dirençli olduğunu belirtmektedir.

Ortalama erozyon oranı değerleri, Kumtaşı anakayası üzerinde bulunan topraklarda \%245.7, Kireçtaşı anakayası üzerinde bulunan topraklarda \%74.76, Kuvarsit anakayas1 üzerinde bulunan topraklarda \%487.4, Mikaşist anakayası üzerinde bulunan topraklarda \%194.2 olarak belirlenmiştir (Şekil 7). Varyans analizi sonuçlarına göre araştırma alanı topraklarının erozyon oranı değerleri bakımından istatistiki anlamda (0.05 yanılma olasılığı ile) farklılık bulunmuştur. Anakaya gruplarından hangilerinin farklılıklar gösterdiğini belirlemek için yapılan Duncan testine göre erozyon oranları bakımından; kireçtaşı ve mikaşist anakayaları ile kuvarsit anakayası arasında önemli farklılıklar tespit edilmiştir (Çizelge 2). Elde edilen Korelasyon analizi sonuçlarına göre ise erozyon oranının; kum miktarı ve permeabilite ile pozitif yönde, kil ve toz miktarı, organik madde ile negatif yönde anlamlı (\%1 yanılma olasılığı ile) ilişki gösterdiği tespit edilmiştir (Çizelge 3).

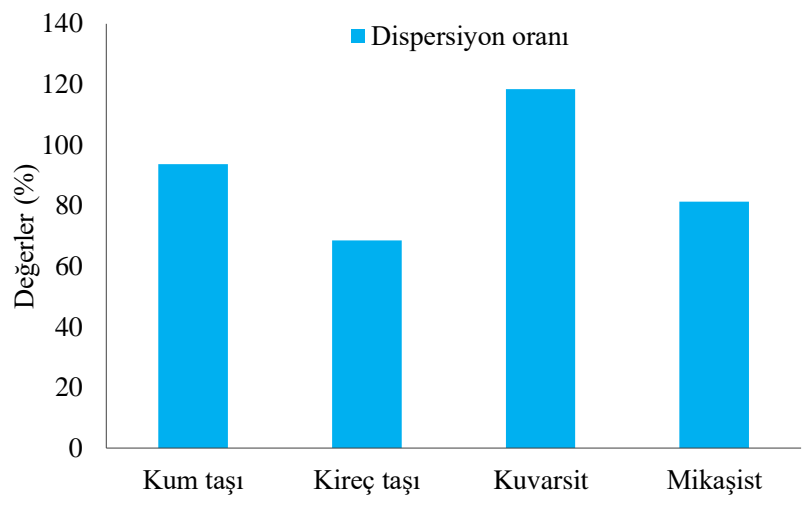

Şekil 5. Farklı anakaya gruplarına göre ortalama dispersiyon oranı değerlerinin değişimi

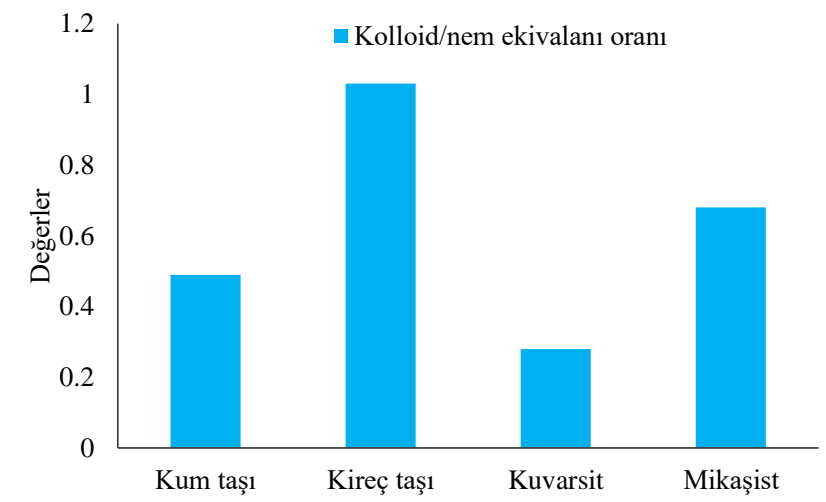

Şekil 6. Farklı anakaya gruplarına göre ortalama kolloid/nem ekivalanı oranı değerlerinin değişimi 
Erozyon oranı, dispersiyon oranı değerinin kolloid/nem ekivalanı oranına oranlanmasıyla elde edilmekte olup, Kuvarsit anakayası üzerinde gelişen toprakların ortalama erozyon oranı değerinin çok daha yüksek olmasının nedeni, yüksek dispersiyon oranına sahip olmasına rağmen düşük kolloid/nem ekivalanı oranına sahip olmasıdır. Schwertman ve Kainz (1990), topraktaki toz ve ince kum oranı ne kadar yüksekse, potansiyel erodibilitenin de o kadar fazla olduğunu belirtmektedirler. Araştırma alanı topraklarının erozyona duyarlılığını artıran temel etmenlerden birisi de iklimsel karakteristiklerdir. Yarı kurak özellikler gösteren araştırma alanında organik maddenin ayrışma hızı fazla olduğundan yapıştırıcı özellik gösteren bu maddelerin hızlı bir şekilde ayrışıp, erozyonla alandan uzaklaşması, bununla birlikte zayıf bitki örtüsü nedeniyle kil gibi erozyona dayanıklılığ artıran taneciklerin alandan taşınması erozyona duyarlılığ artırmaktadır. Anşin (1978), ABD Washington eyaletinde kurak ve nemli iklim koşulları altında gelişmiş bazı orman topraklarının erodibilite karakteristiklerin incelediğ araştırmasında; aynı yağış ve eğim koşullarında, nemli iklime sahip araştırma topraklarının, kurak koşullara sahip araştırma topraklarına göre erozyona karşı daha dayanıklı olduklarını belirlemiştir.

Ortalama kil oranı değerleri, Kumtaşı anakayası üzerinde bulunan topraklarda $\% 7.56$, Kireçtaşı anakayası üzerinde bulunan topraklarda $\% 2.15$, Kuvarsit anakayası üzerinde bulunan topraklarda $\% 20.48$, Mikaşist anakayası üzerinde bulunan topraklarda \%5.49 olarak belirlenmiştir (Şekil 8). Topraklarda kum ve toz değerlerinin artması kil oranı değerinin de artmasına neden olmaktadır. Araştırma alanında Kireçtaşı anakayası üzerinde kum+toz değeri $\% 64.76$, Mikaşist anakayası üzerinde kum+toz değeri \% 80.48, Kumtaşı anakayası üzerinde kum+toz değeri $\% 85.84$ ve Kuvarsit anakayası üzerinde kum+toz değeri \% 93.78 olarak belirlenmiştir. Yapılan Varyans ve Duncan testi sonuçlarına göre \% 5 yanılma olasılığ ile Kuvarsit anakayası üzerinde gelişen toprakların diğer anakaya grupları üzerinde oluşan topraklara göre kil oranı bakımından farklı olduğu belirlenmiştir (Çizelge 2). Elde edilen Korelasyon analizi sonuçlarına göre ise kil oranının; kum miktarı ve permeabilite ile pozitif yönde, kil, toz miktarı ve organik madde ile negatif yönde anlamlı (\%1 yanılma olasılığı ile) ilişki gösterdiği tespit edilmiştir (Çizelge 3). Kil oranı değerine göre erozyona duyarlılığa en yüksekten, en düşüğe doğru sırasıyla Kuvarsit, Kumtaşı, Mikaşist ve Kireçtaşı şeklinde olduğu tespit edilmiştir. Genel olarak söylenebilirki kilce zengin topraklar $\% 40$ dan daha fazla oranda kil değerine, kumlu topraklar $\% 55$ den fazla oranda kum değerine ve balçıklı topraklar kum, kil ve tozun benzer oranlarda bulunduğu topraklardır (Wildman ve Gowans, 1978). Dryness (1967) ve Özyuvac1 (1978), topraklarda toz ve kum oranı artıp kil azaldığında erozyona duyarlılığın arttığını ifade etmişlerdir.Toprak tekstürü toprak erodibilitesini etkileyen önemli bir özelliktir. Topraklardaki toz içeriğinin ve ince kumun artması yüksek erodibiliteye neden olmaktadır. Kilce zengin topraklar ve büzülme şişme kapasitesi düşük olan topraklar daha düşük erodibilite değerleri vermektedir. Bunun nedeni kil taneciklerinin birbirlerine yüzey alanları daha geniş olduğu için herhangi bir kuvvete karşı birbirlerinden kopartılmasının daha zor olmasındandır. Ancak killi topraklar herhangi bir kuvvetle birbirinden kopartıldıktan sonra taşınmaları daha kolaydır. Kumlu toprakların ise birbirinden kopartılması daha kolay ancak taşınmaları için daha büyük enerjiye gerek vardır (O’Geen vd., 2006). Bilindiği üzere tanecik büyüklüğü dağılımı toprakların erozyona karşı hassasiyetlerini etkileyen en önemli toprak özelliği olarak karşımıza çıkmakta (Antal, 1994; Morgan, 1996) ve kil miktarının artışına paralel olarak genel anlamda aşınabilirlik azalmaktadır (Okatan vd., 2000).

Ortalama $\mathrm{K}$ faktörü değerleri, Kumtaşı anakayası üzerinde bulunan topraklarda 0.23 , Kireçtaşı anakayası üzerinde bulunan topraklarda 0.15 , Kuvarsit anakayası üzerinde bulunan topraklarda 0.17, Mikaşist anakayası üzerinde bulunan topraklarda 0.19 olarak belirlenmiştir (Şekil 9). Buna göre, Kumtaşı anakayası üzerinde gelişen topraklar "kolaylıkla aşınabilir" toprak sınıfına, Kireçtaşı, Kuvarsit ve Mikaşist anakayası üzerinde gelişen topraklar "orta derecede aşınabilir" toprak sınıfına girmektedir. Yapılan Varyans analizi sonuçlarına göre araştırma alanı topraklarının K faktörü bakımından istatistiki anlamda (0.05 yanılma olasılığı ile) farklılık bulunmamıştır (Çizelge 2). Elde edilen Korelasyon analizi sonuçlarına göre ise $\mathrm{K}$ faktörünün; kum ve toz miktarı, organik madde, permeabilite ile pozitif yönde, kil miktarı ile negatif yönde anlamlı (\%1 yanılma olasılığı ile) ilişki gösterdiği tespit edilmiştir (Çizelge 3).

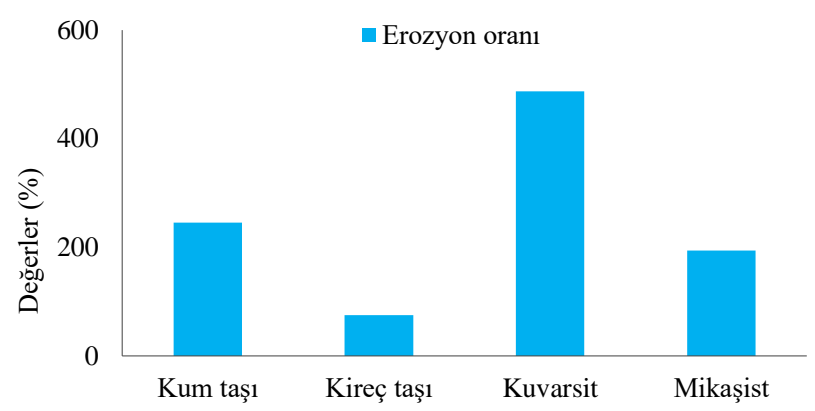

Şekil 7. Farklı anakaya gruplarına göre ortalama erozyon oranı değerlerinin değişimi

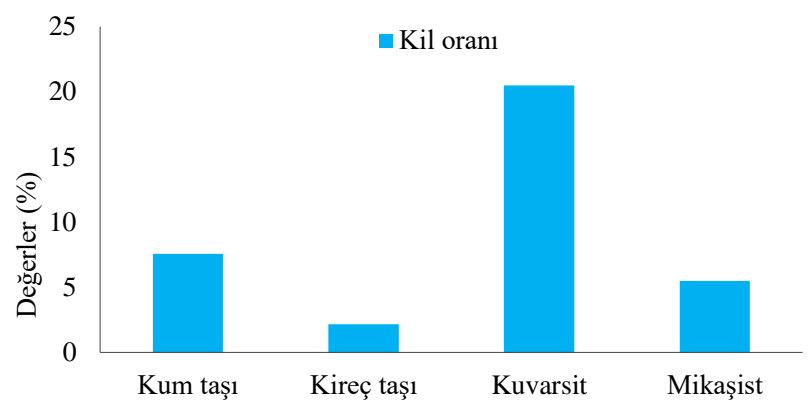

Şekil 8. Farklı anakaya gruplarına göre ortalama kil oranı değerlerinin değişimi

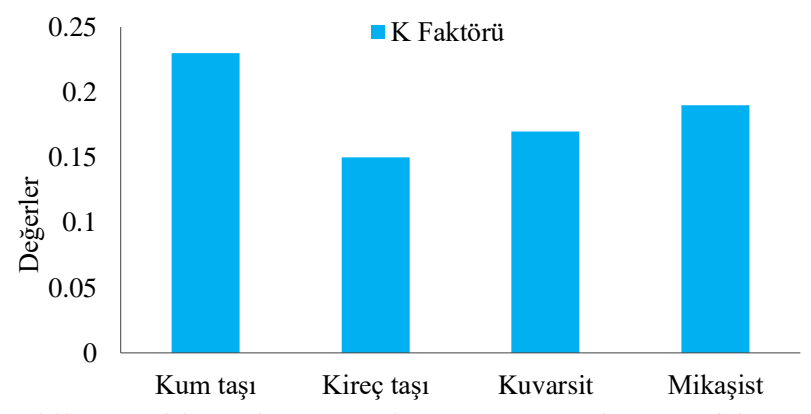

Şekil 9. Farklı anakaya gruplarına göre ortalama K faktörü değerlerinin değişimi 
Çizelge 2. Araştırma alanı topraklarının bazı fiziksel, hidrolojik ve kimyasal özelliklerinin anakaya gruplarına göre değişimi

\begin{tabular}{|c|c|c|c|c|c|c|c|}
\hline $\begin{array}{c}\text { Bazı toprak } \\
\text { özellikleri }\end{array}$ & Anakaya grupları & $\mathrm{n}$ & $\mathrm{X}$ & $\mathrm{Sx}$ & F değeri & Önem düzeyi & $\begin{array}{l}\text { İkili karş1laştırma } \\
\text { (Duncan testi) }\end{array}$ \\
\hline \multirow{4}{*}{ Kum } & Kumtaş1(1) & 14 & 67,4 & 2,34 & \multirow{4}{*}{57,577} & \multirow{4}{*}{, 000} & $(1-2)^{*}$ \\
\hline & Kireçtaşı(2) & 15 & 43,47 & 2,59 & & & $(3-4)^{*}$ \\
\hline & Kuvarsit(3) & 14 & 84,6 & 1,69 & & & $(2-4)^{*}$ \\
\hline & Mikaşist(4) & 13 & 59,56 & 2,40 & & & $(1-3)^{*}$ \\
\hline \multirow{4}{*}{ Kil } & Kumtaşı(1) & 14 & 14,6 & 1,35 & \multirow{4}{*}{50,444} & \multirow{4}{*}{, 000} & $(3-4)^{*}$ \\
\hline & Kireçtaş1(2) & 15 & 35,24 & 2,54 & & & $(3-2)^{*}$ \\
\hline & Kuvarsit(3) & 14 & 6,21 & ,88 & & & $(4-2)^{*}$ \\
\hline & Mikaşist(4) & 13 & 19,63 & 2,08 & & & $(1-2)^{*}$ \\
\hline \multirow{4}{*}{ Toz } & Kumtaş1(1) & 14 & 18,44 & 1,31 & \multirow{4}{*}{15,779} & \multirow{4}{*}{, 000} & \multirow{4}{*}{$\begin{array}{l}(3-1)^{*} \\
(3-2)^{*} \\
(3-4)^{*}\end{array}$} \\
\hline & Kireçtaş1(2) & 15 & 21,29 & 1,35 & & & \\
\hline & Kuvarsit(3) & 14 & 9,18 & 1,40 & & & \\
\hline & Mikaşist(4) & 13 & 20,82 & 1,17 & & & \\
\hline \multirow{4}{*}{ Organik madde } & Kumtaş1(1) & 14 & 3,11 & 0,49 & \multirow{4}{*}{3,379} & \multirow{4}{*}{, 025} & \multirow{4}{*}{$\begin{array}{l}(1-2)^{*} \\
(3-2)^{*}\end{array}$} \\
\hline & Kireçtaş1(2) & 15 & 3,94 & 0,42 & & & \\
\hline & Kuvarsit(3) & 14 & 2,62 & 0,38 & & & \\
\hline & Mikaşist(4) & 13 & 3,14 & 0,66 & & & \\
\hline \multirow{4}{*}{ Permeabilite } & Kumtaş1(1) & 14 & 102,91 & 26,59 & \multirow{4}{*}{1,322} & \multirow{4}{*}{, 277} & \multirow{4}{*}{ (N.S) } \\
\hline & Kireçtaşı(2) & 15 & 43,57 & 12,54 & & & \\
\hline & Kuvarsit(3) & 14 & 101,60 & 28,93 & & & \\
\hline & Mikaşist(4) & 13 & 116,2 & 35,05 & & & \\
\hline \multirow{4}{*}{ Dispersiyon oranı } & Kumtaşı(1) & 14 & 93,69 & 7,09 & \multirow{4}{*}{7,64} & \multirow{4}{*}{, 000} & \\
\hline & Kireçtaş1(2) & 15 & 68,48 & 3,82 & & & $(1-3)^{*}$ \\
\hline & Kuvarsit(3) & 14 & 118,49 & 14,82 & & & $(2-3)^{*}$ \\
\hline & Mikaşist(4) & 13 & 81,36 & 5,01 & & & $(4-3)^{*}$ \\
\hline \multirow{4}{*}{$\begin{array}{l}\text { Kolloid/nem } \\
\text { ekivalanı oranı }\end{array}$} & Kumtaş1(1) & 14 & 0,49 & 0,06 & \multirow{4}{*}{37,32} & \multirow{4}{*}{, 000} & $(3-4)^{*}$ \\
\hline & Kireçtaşı(2) & 15 & 1,03 & 0,07 & & & $(3-2)^{*}$ \\
\hline & Kuvarsit(3) & 14 & 0,28 & 0,02 & & & $(1-2)^{*}$ \\
\hline & Mikaşist(4) & 13 & 0,60 & 0,05 & & & $(4-2)^{*}$ \\
\hline \multirow{4}{*}{ Erozyon oranı } & Kumtaşı(1) & 14 & 245,7 & 70,20 & & & \\
\hline & Kireçtaş1(2) & 15 & 74,76 & 8,37 & 558 & 002 & $(2-3)^{*}$ \\
\hline & Kuvarsit(3) & 14 & 487,4 & 97,02 & 5,58 &, 002 & $(4-3)^{*}$ \\
\hline & Mikaşist(4) & 13 & 194,2 & 96,59 & & & \\
\hline & Kumtaş1(1) & 14 & 7,56 & 1,21 & & & $(2-1)^{*}$ \\
\hline & Kireçtaş1(2) & 15 & 2,15 & 0,20 & & & $(2-3)^{*}$ \\
\hline K1l oran1 & Kuvarsit(3) & 14 & 20,48 & 2,58 & $1 /, 12$ & , & $(4-3)^{*}$ \\
\hline & Mikaşist(4) & 13 & 5,49 & 1,81 & & & $(1-3)^{*}$ \\
\hline & Kumtaşı(1) & 14 & 0,23 & 0,02 & & & \\
\hline Toprak erodibilite & Kireçtaş1(2) & 15 & 0,15 & 0,08 & & & \\
\hline faktörü $(\mathrm{K})$ & Kuvarsit(3) & 14 & 0,17 & 0,05 & 1,78 & , 167 & (N.S) \\
\hline & Mikaşist(4) & 13 & 0,19 & 0,02 & & & \\
\hline
\end{tabular}

*: Önem düzeyi p<0.05, n: Örnek sayıs1; X: Ortalama; Sx: Standart hata

Çizelge 3. Araştırma alanı topraklarının bazı özellikleri arasındaki korelasyon katsayısı

\begin{tabular}{|c|c|c|c|c|c|c|c|c|c|}
\hline & Kil & Toz & $\mathrm{OM}$ & $\mathrm{P}$ & $\mathrm{DO}$ & KNEO & $\mathrm{EO}$ & $\mathrm{KO}$ & $\mathrm{K}$ \\
\hline Kum &,$- 941^{* *}$ &,$- 727^{* *}$ &,$- 391^{* *}$ & ,231 &, $688^{* *}$ &,$- 895^{* *}$ &, $650^{* *}$ &, $783^{* *}$ &,$- 273^{*}$ \\
\hline Kil & & $452^{* *}$ & $397^{* * *}$ &,- 186 &,$- 556^{* *}$ & $961^{\text {** }}$ &,$- 587^{* *}$ &,$- 734^{* *}$ &, $372^{\text {** }}$ \\
\hline Toz & & &, 225 &,- 232 &,$- 684^{* *}$ & $410^{* * *}$ &,$- 521^{* *}$ &,$- 575^{* *}$ &,- 034 \\
\hline $\mathrm{OM}$ & & & &,- 031 &,- 225 &, $302^{*}$ &,- 213 &,$- 314^{*}$ & ,066 \\
\hline $\mathrm{P}$ & & & & &, 251 &,- 223 &, 038 &, 045 & ,197 \\
\hline DO & & & & & &,$- 522^{* *}$ & $682^{* *}$ &, $513^{* *}$ &,- 164 \\
\hline KNEO & & & & & & &,$- 627^{* *}$ &,$- 709^{* *}$ &, $388^{* * *}$ \\
\hline EO & & & & & & & &, $798^{* *}$ &,- 117 \\
\hline $\mathrm{KO}$ & & & & & & & & &,- 149 \\
\hline
\end{tabular}

Erozyona uğramış alanlarda kum yüzdesi yüksek olduğundan, zayıf strüktüre ve düşük organik maddeye sahip topraklar erozyona daha hassastır. Bu görüş Ball (1990) tarafından organik maddenin azalmasının erozyonu arttırdığ ifadesiyle desteklenmektedir. Organik maddenin bağlayıcı etkisi nedeniyle toprakların erozyona daha dayanıklı hale geldiği Charman ve Murphy (1991) tarafindan da desteklenmektedir. Topraklarda düşük kil değerleri ve yüksek kum değerleri $\mathrm{K}$ faktörünün artmasına neden olduğu ve bu toprakların erozyona daha duyarlı olduğu Wawer vd.
(2005) ve Zhang vd. (2007) tarafindan da desteklenmektedir. Topraktaki $\mathrm{CaCO}_{3}$ ve organik maddeden kaynaklı organik karbon agregat oluşumuna önemli katkı yapmakta ve agregat stabilitesini artırarak erodibilite değerini düşürmektedir (Haynes ve Naidu, 1998; Boix vd., 2001; Haynes ve Beare, 1997; Martens, 2000; Plante ve McGill, 2002). Wischmeier ve Mannering (1969), kil ve organik madde miktarı arttıkça erozyona duyarlılığın azaldığını tespit etmişlerdir. Çelebi (1971), toprağın erozyona uğrama eğiliminin belirlenmesinde agregat stabilitesi ile organik madde 
arasında pozitif bir ilişkinin bulunduğunu, kirecin ise stabilite üzerinde organik madde ile birlikte etkili olabileceğini kaydetmiştir. Toz ve ince kum miktarı fazla olan orta tekstürdeki topraklar (balçık topraklar) düşük permeabilite değerlerine ve taşınmaya karşı düşük dayanıklılığa sahiptir (Kantarc1 1980; Richter ve Negendank, 1977; Y1lmaz ve Alagöz, 2008).

Erodibilite toprağın kendi özelliklerinden kaynaklanan erozyona karşı dayanıklılık derecesi olarak ifade edilir (Balcı, 1996). Veihte (2002)'nin belirttiği üzere erodibilite pek çok fiziksel, mekanik, hidrolojik, kimyasal, minerolojik ve biyolojik özelliklerin etkilediği bir sonuçtur. Araştırma alanından farklı anakaya grupları üzerinde gelişen topraklardan elde edilen verilere göre genel olarak tüm erodibilite indeks değerlerine göre anakayaların oluşturduğu toprakların erozyon eğilimleri küçükten büyüğe göre sıralandığında Kireçtaşı, Mikaşist, Kumtaşı ve Kuvarsit şeklinde olduğu belirlenmiştir. USDA (1964), toprakların erodibilitesi üzerine yapılan bir araştırmada; olivin ve bazalt anakayasından gelişen toprakların kuvarsit ve granodiorit anakayasından gelişen topraklara göre erozyona daha dayanıklı olduğunu, bazalt anakayası üzerinde gelişen toprakların erozyona en dayanıklı topraklar olduğunu saptamışlardır. Okatan vd. (2000), Kahramanmaraş Ayvalı Barajı Kızıldere Yağış Havzasında yaptıkları araştırmalarında, toprak profillerinin alınmasında ana faktör olarak anakaya gruplarını dikkate almışlardır. Elde edilen sonuçlara göre kireçtaşı anakaya grubu üzerinde gelişen toprakların dispersiyon oranı değerlerinin tarım alanlarında 11.55-46.05, orman alanlarında $25.00-38.90$ ve mera alanlarında 26.82-49.32 değerleri arasında değiştiğini; kumtaşı anakaya grubu üzerinde gelişen toprakların dispersiyon oranı değerlerinin tarım alanlarında 11.71-40.71, orman alanlarında 7.02-30.30 ve mera alanlarında 12.2554.80 değerleri arasında değiştiğini belirlemişlerdir.

\section{Sonuç ve öneriler}

Araştırma alanı topraklarının genellikle kumtaşı, kireçtaşı, kuvarsit ve mikaşist anakayaları üzerinde gelişim gösterdiği ve bu anakayalar üzerinde gelişen toprakların balçıklı kum ile kumlu kil arasında değişen tekstürlere sahip olduğu ortaya konmuştur.

Farklı anakayalar üzerindeki topraklar erodibilite indeksleri bakımından erozyona duyarlı tespit edilmiştir. Kuvarsit anakayası üzerinde gelişen topraklar erozyon oranı, kil oranı ve dispersiyon oranı bakımından diğer anakaya gruplarına göre erozyona daha duyarlı olduğu belirlenmiştir. Dolayısıyla elde edilen verilere göre anakayanın toprak özellikleri üzerine etkili olduğu tespit edilmiştir.

Ortalama dispersiyon oranı değerleri bakımından en yüksek değer Kuvarsit anakayası üzerinde gelişen topraklarda; ortalama kolloid/nem ekivalanı oranı bakımından en yüksek değer Kum taşı anakayası üzerinde gelişen topraklarda; ortalama erozyon oranı ve kil oranı değerleri bakımından en yüksek değer Kuvarsit anakayası üzerinde gelişen topraklarda ve ortalama toprak erodibilite faktörü değerleri bakımından en yüksek değer Kum taşı anakayası üzerinde gelişen topraklarda tespit edilmiştir.

Yapılan arazi ve laboratuvar çalışmaları sonucunda araştırma alanındaki topraklar erozyona duyarlı bulunduğundan; toprakların mutlaka korunması için gerekli önlemlerin alınması, ekonomik ve toprağı koruyucu türlerle bitki-toprak-su arasındaki dengenin kurulması öncelikli olmalıdır. Çemrengeç Deresi Yağış Havzasında orman ve mera alanlarına olan baskıyı azaltmak, bu alanların tarım alanlarına dönüştürülmesini önlemek amacıyla orman ve arazi kadastrosunun yapılması gerekmektedir.

\section{Kaynaklar}

Anşin, R., 1983. Türkiye'nin flora bölgeleri ve bu bölgelerde yayılan as1l vejetasyon tipleri. İ.Ü. Orman Fakültesi Dergisi, 6(2): 318339.

Antal, J., 1994. Erosion Factors. Soil Conservation and Silviculture (Eds: Dvorak, J. and Novak, L.). Elsevier.

Aydın, M., 2000. Giresun Yağlıdere yağış havzasında farklı anamateryaller üzerinde gelişen toprakların erozyon eğilim değerleri ve vejetasyon yapısı üzerine araștırmalar. Yüksek Lisans Tezi, Karadeniz Teknik Üniversitesi, Fen Bilimleri Enstitüsü, Trabzon.

Babalık, A.A., 1999. Erozyon ve Türkiye. T.C. Orman Bakanlığ 1 Teknik Bülteni, Sayı: 6, Sayfa: 3, Ankara.

Balc1, A.N., 1978. Erodibility Characteristics of Some Forest Soils Developed under the Influence of Arid and Humid Climatic Conditions, İstanbul Üniversitesi Orman Fak. Yayınları, Orm. Fak. Yayın No: 248, İstanbul.

Balc1, A.N., 1996. Toprak Koruması Ders Notları. İ.Ü. Orman Fak., Yay. No: 439, Üniversite Yayın No: 3947, İstanbul.

Ball, A., 1990. Soil Properties and Their Uses. John Wiley and Sons. London.

Boix- Fayos, C., Calvo- Cases, A., Imeson, A., 2001. Influences of soil properties and the aggregation of some mediterranean soils and the use of aggregate size and stability as land degradation indicators. Catena, 44: 47-67.

Bouyoucos, G.J., 1935. The clay ratio as a criterion of the susceptibility of soil to erosion. Jour, Am. Soc. Argon, 27: 738741.

Charman, P.E., Murphy, B.W., 1991. Soil Their Properties and Management. Oxford University Press, New York.

Çelebi, H., 1971. Toprak Erozyonu. Atatürk Üniversitesi Ziraat Fakültesi Yayınları, No: 37, Erzurum.

Çepel, N., 1988. Orman Topraklarının Karakteristikleri, Toprakların Oluşumu, Özellikleri ve Ekolojik Bakımdan Değerlendirilmesi. Toprak İlmi Ders Kitabı, İ.Ü. Orman Fakültesi Yayınları Yayın No: 3416, İstanbul.

Doğan, O., Cebel, H., Akgül, S., Küçükçakar, N., 2000. Türkiye Büyük Toprak Grupları (K) Faktörleri Köy Hizmetleri. APK Dairesi Başkanlığı Toprak ve Su Kaynakları Araştırma Şube Müdürlüğ̈̈, Yayın No:111, Rehber No: 17, Ankara.

Doğan, O., Güçer, C., 1976. Su erozyonunun nedenleri, oluşumu ve üniversal denklem ile toprak kayıplarının saptanması. T.C. Köy İşleri Bak. TOPRAKSU Genel Müd. TOPRAKSU Araş. Enst. Müd. Yay. No: 41, Ankara, 159s.

Dryness, C.T., 1967. Erodobility and Erosion Potential of Forest Watersheds. Symposium on Forest Hydrology, Pergamon Press, London.

Erol, A., Babalık, A.A., Sönmez, K., Serin, N., 2009. IspartaDarıderesi Havzası topraklarında erozyona duyarlılığın arazi kullanım şekillerine bağlı değişimi. Süleyman Demirel Üniversitesi Orman Fakültesi Dergisi, A (2), 21-36.

Evans, R., 1980. Mechanics of Water Erosion and Their Spatial and Temporal Controls; an Empirical Viewpoint. In Kirkby, N. Y. And R.P.C. Morgan, (Eds.), Soil Erosion, Wiley, 109-128.

Farmer, E.E., 1973. Relative detactibility of soil particles by similated rainfall. Soil Science Society of America Proceedings, 37(4): 629-633.

Gülçur, F., 1974.Toprağın Fiziksel ve Kimyasal Analiz Metodları. İ.Ü. Orman Fakültesi. Yay. No: 201, İstanbul.

Günay, T., 2008, Orman, Ormansızlaşma, Toprak, Erozyon, TEMA Vakfi Yayınları, Yayın No:1, ISBN: 978-7169-05-5, İstanbul.

Haynes, R.J., Beare, M., 1997. Influence of six crop species on aggregate stability and some labile organic matter fractions. Soil Biol. Biochem., 29: 647-1653. 
Haynes, R.J., Naidu, R., 1998. Influence of lime, fertilizer and manure applications of soil organic matter content and soil physical conditions: A rewiew. Nutr. Cycl. Agroecosyst., 51: 123-137.

Kantarci, M.D., 1980. The research on distinguishing and mapping of forest site unity and soil types in Belgrade forest. Istanbul University Faculty of Forestry publication No: 2636, İstanbul.

Kantarc1, M.D., 1987. Toprak İlmi, İ.Ü. Orman Fakültesi Yayınları, İ.Ü. Yayın No: 3444, Orman Fak. Yayın No: 387, Matbaa Teknisyenleri Basımevi, İstanbul.

Kantarc1, M.D., 2000. Toprak İlmi. İ.Ü. Orman Fak. Yayınları, İ.Ü. Yayın No: 4261, Orman Fak. Yayın No: 462, Çantay Matbaası, İstanbul.

Karagül, R., 1999. Investigations on soil erodibility and some properties of soils under different lnd use types in Soğutludere creek watershed near Trabzon. Turkish J. Agric. For., 23: 53-68.

Lal, R., 1988. Soil Erosion Research Methods, Soil and Water Conservation Society, ISBN 0-935734-18-X, St. Lucie, USA.

Lutzh, J.H., Chandler, F.R., 1947. Forest Soils. John Wiley and Sons Inc., New York.

Martens, D.A., 2000. Plant residue biochemistry regulates soil carbon cycling and carbon sequestration. Soil Biol. Biochem., 32: 361-369.

Morgan, R.P.C., 1985. Soil erosion measurement and soil conservation research in cultivated areas of the UK. Journal of Geography, 151: 11-20.

Morgan, R.P.C., 1996. Soil Erosion and Conservation. AddisonWesley Boston MA.

Ngatunga, E.L.N., Lal, R., Singer, M.J., 1984. Effect of surface management on run off and soil erosion from some plot Milangano, Tanzania. Geoderma, 33: 1-12

O’Geen, A. T., Elkins, R., Lewis, D., 2006. Reducing Runoff from Irrigated Lands: Erodobility of Agricultural Soils, with Examples in Lake and Mendocino Counties.

Okatan, A., 1986. Trabzon-Meryemana Deresi Yağış Havzası Alpin Meralarının Bazı Fiziksel ve Hidrolojik Toprak Özellikleri ile Vejetasyon yapısı Üzerine Araştırmalar. Doktora Tezi, Karadeniz Teknik Üniversitesi, Fen Bilimleri Enstitüsü, Trabzon

Okatan, A., Yüksel, A., Reis, M., 2000. Kahramanmaraş ayvalı barajı kızıldere yağış havzasında toprakların erozyon eğilim değerlerinin hidrofiziksel toprak özelliklerine bağlı olarak değişimi. Fen ve Mühendislik Dergisi, 3(1): 28-42.

Özhan, S., 2004. Havza Amenajmanı Ders Kitabı. İstanbul Üniversitesi Orman Fakültesi, Havza Amenajmanı Anan Bilim Dalı Rektörlük Yayın No: 4510, Orman Fakültesi Yayın No: 481, İstanbul.

Öztan, Y., 1980. Meryemana Deresi Havzasında değişik bakılardaki orman ve mera arazileri topraklarının erozyon eğilimi (erodibility) değerlerindeki farklılıklarının araştırılması. KTÜ Orman Fak. Dergisi, 3(2): 185-213.

Özyuvacı, N., 1978. Kocaeli Yarımadası Topraklarında Erozyon Eğiliminin Hidrolojik Toprak Özelliklerine Bağlı Olarak Değişimi. İ.Ü. Orman Fak. Yay. No: 233, İstanbul.
Özyuvac1, N., 1975. Topraklarda Erozyon Eğiliminin Tahmini Açısından Yapılan Bazı Değerlendirmeler. TÜBİTAK V. Bilim Kongresi, Tarım ve Ormancılık Araştırma Grubu Tebliğleri Ormancilık Seksiyonu, 29, 123-134.

Plante, A., McGill, W., B., 2002. Soil aggregate dynamics and the retention of organic matter in laboratory- incubated soil with differing simulated tillage frequencies. Soil Tillage Res., 66: 7992.

Reis, M., 1997. Trabzon-Araklı-Karadere Yağış Havzası orman içi meralarının bazı fiziksel ve hidrolojik özellikleri ile vejetasyon yapısı üzerine araștırmalar. Yüksek Lisans Tezi, Karadeniz Teknik Üniversitesi, Fen Bilimleri Enstitüsü, Trabzon.

Richter, G., Negendank, J.F.W., 1997. Soil erosion processes and their measurement in the German area of the Mosella River. Earth Surface Processes, 2: 261-278.

Schwertmann, U.W.V., Kainz, M., 1990. Bodenerosion Durch Wasser-Vorhersage Des Abtrags Und Bewertung von Gegenmaßnahmen.

Sönmez, K., 1994. Toprak Koruma Ders Kitabı. Atatürk Üniv. Ziraat Fak. Yayınları. No: 169, S.192, Erzurum.

U.S. Department of Agriculture, 1964. Soil Erodibility Related to Rock Types in California, Ext. From Rep. Pacif. Sthwest. For Range. Exp. Sta., USDA Pasific Southwest Forest and Range Experiment Station, 33p.

Veihte, A., 2002. The spatial variability of erodobility and its relation to soil type: A study from Northern Ghana. Geoderma, 106: 101-120.

Wawer, R., Nowocien, E., Podolski, B., 2005. Real calculated KUSLE erodibility factor for selected polish soils. Polish J. Environ. Stud., 14(5): 665-658.

Wildman, W.E., Gowans, K.D., 1978. Soil physical environment and how it affects plant growth. Oakland: University of California Division of Agricultural Sciences, Leaflet 2280.

Wischmeier, W.H., Mannering, J.V., 1969. Relation of soil properties to erodibility. Soil Sci. Soc. Amer. Proc., 33: 131-137.

Yamanlar, O., 1962. A new erosion classification suited for Turkey conditions. Rewiev of Istanbul University, Faculty of Forestry, Serial B, XII: 53-66.

Yazici, N., Turan, A., 2016. Effect of forestry afforestation on some soil properties: A case study from Turkey. Fresenius Environmental Bulletin, 25(7): 2509-2513.

Yılmaz, E., Alagöz, Z., 2008. Toprak bozulması. Selçuk Üniversitesi Ziraat Fakültesi Dergisi, 2(45): 58-65.

Yüksek, T., 2001. Rize-Pazar Deresi Yağıs Havzasında farklı arazi kullanım şekilleri altındaki toprakların bazı özellikleri ile aşınım eğilimi değerlerinin araștırılması. Doktora Tezi, Karadeniz Teknik Üniversitesi, Fen Bilimleri Enstitüsü Trabzon.

Zhang, Z.G., Fan, B.E., Bai, W.J., Jiao, J.Y., 2007. Soil antierodibility of plant communities on the Removal lands in HillyGully Region of the Loess Plateau. Science Soil Water Conser., 5: 7-13. 